\title{
SIKERES KISVÁLLALKOZÁS - EREDMÉNYES MARKETING? KISVÁLLALATI ESÉLYEK AZ ÉLELMISZERPIACON
}

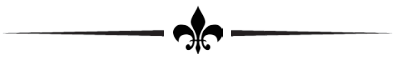

\author{
SUCCESSFUL SMALL BUSINESS - EFFECTIVE MARKETING? \\ PROSPECTS ON THE FOOD MARKET FOR A SMALL COMPANY
}

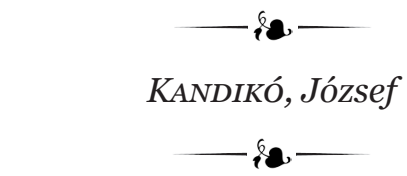

Edutus Főiskola, Kereskedelem és marketing tanszék (Edutus College, Department for Trade and Marketing) H-28oo Tatabánya, Stúdium tér 1. e-mail: kandiko.jozsef@edutus.hu

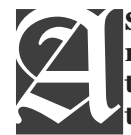

Successful small companies concentrate their marketing strategy on satisfying the specific requirements of market niches which are unprofitable for big concerns. It is a complicated task on the market of common consumer goods - like the food market - because it is difficult to find the right buyer segment among the large number of costumers. It is more difficult to choose the adequate distribution and communication channels. The Darnó-Hús (Darnó Meat) situated in the north-west of Hungary near the Austrian and the Slovakian borders - also faces this problem. Firstly, they do not choose between traditional local food and functional foods, so they obviously aim at two niches. Secondly, small well-branded bakery shops and big supermarkets can be found among the company's sales points. Furthermore, these sales points are geographically not concentrated. This small company cannot afford to spend much on widespread media communication, so its brand name is not well-known enough to get good product placement locations in the stores. As the SWOT-analysis, which was carried out with the collaboration of the management, points out, there is no unity in the choice between the offensive and defensive strategies. The internal factors of the company, such as high-quality products and excellent professional team, which is flexible enough to fulfil the specific requirements, would assign the company a stronger market position, however, the company's management does not have adequate marketing tools to achieve a higher penetration into the consumer market. After twenty years in operation, they have to make a decision about the next stage of development. Actually before they start to improve their production capacity, the management has to define their market more precisely. To reach the targeted market niche effectively, more effective branding, clear - emotional and rational - positioning in communication, and adequate selling placement are needed. 


\section{BEVEZETÉS - INTRODUCTION}

A Magyar Termék Nagydíj 2016. évi pályázatának meghirdetése alkalmából összehívott sajtótájékoztató utolsó felszólalója az egyik korábban már kétszer is díjazott - hazai vállalkozás, a Darnó-Hús résztulajdonos vezetője volt, aki rövid, érdekes és tényszerü tájékoztatót tartott a cégről és termékeiről. A marketing szempontból jól felépített bemutató felkeltette az érdeklődésemet, és a sikeresnek látszó kisvállalkozásról egy esettanulmány elkészítésére kértem és kaptam lehetőséget a tulajdonostól.

Arra voltam kíváncsi, hogy vajon mennyire érvényes még az a jó tíz évvel ezelőtti (a tej- és húsipari vállalkozások körében végrehajtott kutatás eredményeként megfogalmazott) megállapítás: „...a kis- és közepes vállalkozások elhanyagolják a marketing területét, a stratégiai tervezés hiánya állapítható meg, aminek fó okaként a forráshiányt jelölték meg a vállalkozások vezetői." (POLERECZKI és SZABÓ, 2005:25). Az ezt követő években több doktori értekezés is foglalkozott a KKV-k marketingtevékenységével, és a többségük arra a megállapításra jutott, hogy e vállalati kör többsége egyáltalán nem vagy csak egyes elemeiben készít marketingterveket (KARDA, 2009; MAGYAR, 2009; POLERECZKI, 2011; KATONA, 2014). Azóta is hasonló következtetéseket lehet levonni a számos kisvállalatról készülő felsőoktatási szakdolgozatból is.

Az esettanulmány módszertant azért gondoltam elfogadhatónak, mert ezzel egy sikeresnek látszó kisvállalat marketingdöntési mechanizmusába kaphatunk betekintést. A példának választott cég pedig azért is érdekes, mert jól ismert, hogy a magyar húspiac mennyire koncentrált. 2012-ben az 594 húsfeldolgozó vállalkozásból mindössze $24(4,2 \%)$ volt nagyvállalat, de ők adták az árbevétel több mint felét (KÜRTHY, 2015). Ilyen piaci környezetben egy látszólagos piaci sikerrel büszkélkedő kisvállalkozás esete tanulságul szolgálhat más KKV-k számára.

\section{ANYAg ÉS MÓDSZER -}

\section{Material AND Method}

\subsection{Szekunder kutatás - Secondary Research}

Az esettanulmány elkészítéséhez a szekunder és a primer kutatás módszereit egyaránt felhasználtam. A szekunder kutatás elsősorban a témakörhöz kapcsolódó szakirodalom tanulmányozására irányult: a KKV-marketing, a résmarketing stratégiák, valamint az élelmiszer- és táplálkozásmarketing témakörében megjelent könyveket, szakcikkeket, tanulmányokat, kutatási jelentéseket tekintettem át. Több, a témában releváns doktori értekezés is látókörömbe került, amelyek hasznos friss empirikus kutatási információkkal szolgáltak.

A konkrét céggel kapcsolatos szekunder információk részben a vállalattól kapott nyomtatott forrásokból (termékkatalógus, termék információs lapok, referencia levelek) származnak, de többnyire az Interneten feltárható ismeretek begyüjtése és értékelése volt a feladatom. Nagyon sok információ volt elérhető a cég honlapján, de több élelmiszeripari és kisvállalkozói hírportál is bőven szolgáltatott figyelemre méltó híreket a cégről.

Ezekből a forrásokból megtudhatjuk, hogy a szigetközi Darnózseliben 1991-ben alakult Funkció Kft. Darnó-Hús nevü húsfeldolgozó üzeme 1995-ben jött létre. A 2014-es és 2015-ös pályázatokon összesen kilenc termékük nyerte már el a Magyar Termék Nagydíjat. Termékeit - igaz csak kis mennyiségekben - de már nyolc országba exportálja, és a családból már három generáció dolgozik együtt a gyorsan növekvő kisvállalkozásban.

Fényképes termékkatalógus mutatja be a hat klasszikus hús-termékcsoportba sorolt 61 terméket, valamint a két fantázia nevü „egészségforrás” illetve „múltidéző” - termékcsaládba sorolt hat díjazott tereméket, továbbá hét 2016-ban bevezetett újdonságot. A rendezvényen kapott információs anyagok között 
kezembe került egy kis kártya, amelyet a múltidéző termékcsaládba sorolt Szigetközi házikolbászról mellékelt a cég: „A Duna alakította Szigetköz mocsaras, nádas szigetvilága mellett élő böllérek nemzedéke évszázadokon keresztül adta át egymásnak a hús tartósításának e nemes tudományát. A téli disznóölések alkalmával elkészített, $\mathrm{s}$ a padláson érlelt Szigetközi házikolbászt még a Péter-Pál napi aratáskor, a kifent kaszák mellett is fogyaszthatták, vélhetően a speciális mikroklímának köszönhetően. Nagyapáink ránk ruházott tudományát mi nagy becsben tartva míveljük tovább és büszkén ajánljuk az Ön asztalára!” Jól hangzik ez, és igazi hagyományos termékre tesz ígéretet, de hogy jön ide akkor a „Tengeri sóval!” felülírás?

A honlapról erre is kapunk magyarázatot: „Üzletpolitikánk része, hogy olyan élelmiszerek előállítására törekszünk, amelyek nemcsak az ízviláguk miatt állnak közel a vásárlóinkhoz, hanem megfelelnek a jelen korban egyre jobban előtérbe kerülő egészségtudatos táplálkozás elvárásainak is. ... Törekszünk arra, hogy termékeink a lehető legkevesebb, (és lehetőség szerint természetes alapú) segédanyagok felhasználásával készüljenek. Az egészségtudatosság jegyében termékeinket tengeri sóval készítjük. Megalkuvás nélkül ragaszkodunk a legjobb minőségü alapanyagokhoz és ezek termékké formálódásának minden lépését hentesmesterek gondosan felügyelik. A funkcionális termékfejlesztés során, a sertéshúsból készített termékek kedvezőtlen zsírsavösszetételét változtattuk meg. A gyártmányfejlesztésnek köszönhető termékek esetében omega-3 zsírsavakban gazdag olajforrással, (magas ALA-tartalmú lenolaj), helyettesítettük a húskészítmények előállításánál használt zsírforrás (szalonna) egy részét.” (DARNÓ-HÚS, 2016).

Érthető, a termékcsaládok elnevezésében is megismerkedtük már velük: egyrészt „múltidéző”, másrészt „egészségforrás” kínálattal van jelen a cég a piacon. Felmerül azonban a kérdés: melyik célcsoportnak, milyen marketingeszközökkel?

\subsection{Primer információk begyújtése - Collection of Primary Information}

A szekunder információk egy sereg nyitott kérdést hagytak, szükség volt a primer információkra is. A vállalattal való mélyebb megismerkedés céljából, az adatok összegyưjtése a személyes mélyinterjúk módszerével zajlott a cég székhelyén. Beszélgető partnereim (az ügyvezető Kanyóné Princes Gyöngyi és a Nyugat-Magyarországi Egyetem címzetes docenseként is bemutatkozó résztulajdonos, Dr. Kovács Péter) - miután egy kérdéslistát előzetesen megkaptak - felkészülten fogadtak az első interjún.

Az első szigetközi utazás előtti kérdéseimmel a marketingtervezés folyamatát, lépéseit, választ igénylő kérdésit - a releváns magyar szakirodalom alapján - foglaltam össze. A kérdések világosok, útbaigazítást is adnak (REKETTYE, 2007; 2012).

Kik a vevők?

A termék mely tulajdonságai miatt felel meg ennek a vevőkörnek?

Milyen áron lehet a termékeket eladni e vevők számára?

Milyen úton, csatornákon lehet eljuttatni terméket a vevőhöz?

Hogyan kell és lehet tájékoztatni ezeket a potenciális vevőket?

Miképpen lehet kommunikálni ezekkel a vevőkkel?

A kisvállalati marketing is a jól ismert marketingeszközöket használja, bár a piacméret és a vállalati erőforrások korlátjai miatt ezeket erősen szelektálni kell, hogy az adott réspiacon sajátos szempontok szerint kialakított célrendszer elérését segítsék.

Kérdéseim tehát elsősorban a célcsoportra és a pozicionálási elképzelésekre vonatkoztak, továbbá a termékfejlesztési preferenciákat, az alkalmazott értékesítési csatornákat és a marketingkommunikációs döntések sajátosságait szándékoztam megismerni. Az első interjú után 
összeállt kép nem volt elégséges a megalapozott értékítélethez, ezért egy későbbi időpontban a cég SWOT-elemzését végeztük el közösen a menedzsment által kijelölt vezető munkatársi csoportban. A vezetőség is fontosnak tartotta ezt, hiszen - elmondásuk szerint - korábban is végeztek ilyen önvizsgálatot, de már vagy három éve nem frissítették ismereteiket ilyen módon. A tényezők feltárását a nominális csoport módszer szisztematikus alkalmazásával hajtottuk végre (KINDLER, 1978).

A múhelyvita formájában megszervezett elemzési folyamatban a cég felelős munkaköreit ellátó 10 fő vett részt (kilenc vezető jelen volt, egy fó írásban küldte el, hogy miket tart a vállalkozás erősségeinek, gyengeségeinek, illetve a külső környezetből fakadó lehetőségeknek és veszélyeknek). A kialakult kép tehát a teljes vállalati létszám egyötödének véleményét tükrözi, és benne megjelenik két résztulajdonos, továbbá az egyik tulajdonos marketing szakdolgozatát író fiának a véleménye is, aki a Budapesti Gazdasági Egyetem végzős diákjaként jelenleg éppen szakmai gyakorlatát tölti a cégnél.

Az összegyújtött szekunder és primer információk alapján az elemzési módszerem is a fenti kérdéssort követi. Megvizsgáljuk tehát, hogy a Darnó-Hús menedzsmentje által a marketingtervezés logikus kérdéseire adott válaszok mennyire mutatnak egyértelmü irányvonalat a cég marketingmunkájához, piaci lépéseihez; hogyan áll össze egy résmarketing stratégia megvalósításának vezérfonala.

\subsection{A Darnó-Hús a piacon, forgalmi adatok - Darnó-Hús on the Market, Turnover Data}

A Funkció Kft. húsfeldolgozó üzemének termékei a kezdetek óta a „Darnó-Hús a Szigetközből" szlogennel kerülnek forgalomba. Az 1995-ben három fővel indult termelés kezdetben 15-20 féle terméket jelentett, amit néhány környékbeli kisbolt pultjain árusítottak.

A pontosság és a relevancia kedvért szólni kell a cég saját piacán betöltött helyéről, nagyságrendjéről. A személyes megbeszélés kezdetén gyorsan tisztázódott, hogy egy dinamikusan fejlődő kisvállalkozásról van szó. A Darnó-Hús termékek gyártása 48 alkalmazottal zajlik. Árbevételük 2015-ben 1,14 milliárd forint volt, a cég tehát még biztosan ôrzi a jogszabályban meghatározottak szerinti kisvállalati besorolást.

$\mathrm{Az}$ árbevétel növekedése folyamatos, miután a 2012-2013-ban kapott 57,6 millió forintos vissza nem térítendő támogatás segítségével egy 121 millió forintos technológiai modernizálást valósítottak meg. A fejlesztések révén a cég kapacitása a háromszorosára bővült.

Ez a 2015-ben 1,14 milliárd forintos árbevétel a belföldi sertés hús- és húskészítmények piacán gyakorlatilag nem kimutatható piacrészesedésű piaci szereplőt takar.

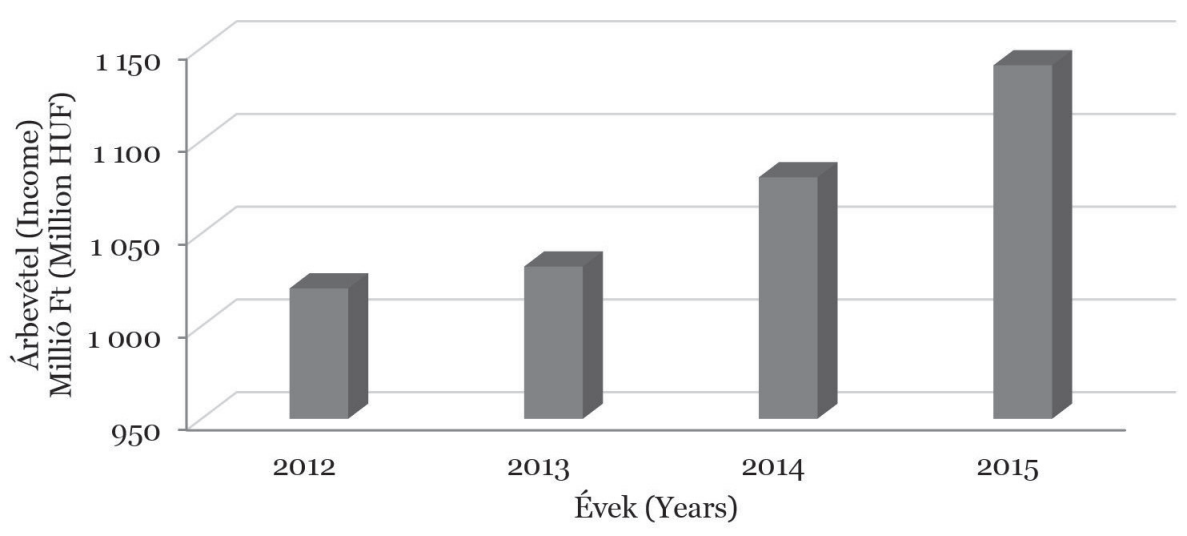

1. ÁBRA

A Darnó-Hús árbevétele

(Income of the Darnó-Hús)

Forrás (Source): Vállalati adatok (Data from company)

FIG. 1 


\section{EREDMÉNyeK - Results}

\subsection{Marketing célok és eszközök - Marketing Objectives and Tools}

Darnó-Hús vezetése számára a termékeik márkaneve, és ennek erősítése a legfontosabb piaci cél. Bár tisztában vannak azzal, hogy teljes termelési mennyiségük a magyar hús- és húskészítmény piacnak csak töredéke, mégis meggyőződésük, hogy az igényes, a minőséget értékelő és tudatos fogyasztók körében biztosan van helyük a piacon, akár országszerte. Erre predesztinálja őket a hagyományos, helyi ízek felkarolása. Ebben a törekvésben szánnak nagy szerepet annak a már néhány éve bevezetett újításnak, hogy a hagyományos sót tengeri sóval helyettesítik, és csökkentették a felhasznált só mennyiségét is a termékeikben.

Mostanra már szinte minden termékükből számüzték az allergéneket is: glutén már csak a hurkába kerülő zsúrkenyérben található, laktóz pedig a sajtos párizsiban van. „Valamivel meg akarjuk különböztetni magunkat a többi, nagytömegben kínált hústerméktől" - hangzott az ügyvezetó érvelése. Persze felismerték ők is, hogy ez a „-mentes” mánia nem csak a dietetikus kényszer vagy az egészségtudatosság megnyilvánulása, hanem bizony trendi is. Ezért szerepel a termékeik többségénél az allergénmentes jelző. Ezekról tanúskodnak a termékpalettát és a termékfejlesztési elveket bemutató információk, amelyeket már a honlapról is megismerhettünk.

\subsection{Pozícionálás: emocionális vagy racionális stratégia - Positioning: Emotional or Rational Strategy}

A hagyományos ízek preferálása a vezetés részéről teljesen érthető, mondhatjuk, hogy egyértelmű emocionális pozícionálás. Korábbi kutatási eredmények igazolják ugyanis, hogy a vásárlók a megfogható, érzékelhető tulajdonságok mellett a magyar eredetet és ezen belül az adott régióhoz való tartozást is fontosnak tartják. A származási hely, eredet, hagyományos jelleg fontos bizalmi termékösszetevők. Ezeket alátámaszthatja a csomagoláson szereplő védjegy, hiszen a fogyasztók valamilyen bizonyosságot akarnak a származási hely ha- gyományosságáról, amit számukra a védjegy vagy a földrajzi eredetre utaló logó jelenít meg (POPOVICS és GYENGE, 2016).

A új $\mathrm{K}+\mathrm{F}$ eredmények felhasználására vonatkozó vállalati információk (amiról nemcsak a cég honlapján, hanem több vezetői megnyilatkozásból is bővebben tájékozódhatunk) azonban már a funkcionális élelmiszerek piacára való betörés gondolatát vizionálja. Ez is helyénvaló elképzelés, mert a kutatások feltárták, hogy a XXI. századi értékváltás jeleként a magyar fogyasztók többet törődnek egészségükkel, jobban odafigyelnek az egészséges táplálkozásra, ami összefügg a megváltozott életstílusukkal. Ezek a változások új kihívás elé állítják az élelmiszeripart, hiszen a vállalatoknak olyan új élelmiszereket kell kifejleszteniük, amelyek egészségvédő hatásuk révén megelőzik, illetve lassítják az emberiséget sújtó civilizációs betegségek terjedését, az idősödő társadalmaknak pedig hosszabb egészségben eltöltött élettartamot biztosítanak. Az ilyen új típusú élelmiszereket összefoglaló néven funkcionális élelmiszereknek nevezi a szakma (SZAKÁLY, 2009). Ezzel a Darnó-Hús a racionális pozícionálás mellett is letette a voksot, termékkínálatában növekvő számba jelennek meg az ilyen termékek, kommunikációjukban párhuzamosan emlegetik a hagyományos ízekkel.

A Darnó-Hús vezetési filozófiájában tehát az érzelmi és a tudatos megközelítés ellentmondása is egyértelmüen tetten érhető. Ezt vállalják akkor is, ha egy 2014-es kutatás eredményeit összegző szakcikkben a szerzők arra a megállapításra jutottak, hogy „...a magyar fogyasztók táplálkozási szokásai még mindig a tradicionális elvet követik, a klasszikus értékek úgy, mint az élelmiszerek élvezeti értéke, kiváló íze lényegesen fontosabbak, mint például az új értékek közé sorolható egészségtudatosság." (SZAKÁLY, KISS és JASÁK, 2014:16).

Egy viszonylag szerény mennyiséggel a piacon lévő vállalkozás számára fontos üzenete van annak, hogy a magyar lakosság fele nem akar változtatni régi táplálkozási szokásain, és mindössze $5 \%$ azok aránya, akik a vizsgálat előtti fél évben áttértek egy általuk egészségesebbnek vélt táplálkozási módra. Jogos a kérdés, hogy most akkor melyik igények kielégítésére koncentráljon egy élelmiszeripari kisvállalko- 
zás. Ebből ráadásul igen komoly kommunikációs döntések is következnek. A hagyományos ízek, termékek bemutatása klasszikus képekkel, emocionális érveléssel egyértelmü, és a fogyasztók számára is könnyen érthető. A kutatók megállapítása szerint azonban hatalmas kommunikációs rés mutatható ki a funkcionális, egészségvédő élelmiszerek termékinformációi és a fogyasztók információbefogadása között. E termékek a piacon a tudomány racionális érveivel kapnak támogatást, a felszívódási, humánklinikai vizsgálati eredményekről, bioaktív összetevőkről szólnak az információk, amiket a vevők nehezen értelmeznek. Ennek következtében a vásárló elbizonytalanodik és tartózkodik a vásárlástól (SZAKÁLY, KISS és JASÁK, 2014).

A tudomány és a fogyasztó közötti kommunikációs rés az eltérő gondolkodásmód miatt alakul ki, és a piac termékelfogadási folyamatát alapvetően meghatározza. Ezért nem célszerü keverni a két pilléren nyugvó termékpozícionálást. A Darnó-Húsnál ez csak azért nem okozott eddig komolyabb problémát, mert a cég egész kommunikációja nagyon visszafogott és a piaca szúk.

\subsection{Vevők, szegmensek és célcsoportok - Customers, Segments and Target Groups}

A pozícionálásban, mint marketingstratégiai döntésben felismerhető disszonancia miatt érthetően nagy kíváncsisággal vártam a választ a cég vásárlói célcsoportjait firtató kérdésemre. Vevőszegmenseiket az 1. táblázatban látható módon jellemezte az ügyvezető.

Vevők szerinti értékesítés (Turnover by Customers)

\begin{tabular}{ll}
\hline \multicolumn{1}{c}{ Vevő megnevezése (Name of the Customers) } & $\%$ \\
\hline Húsboltok (Butchers) & 20 \\
\hline Üzemi konyhák (Big kitchens) & 35 \\
\hline Nagykereskedők, benne a Tesco (Wholesalers incl. Tesco) & 15 \\
\hline ABC - szegmens, élelmiszerboltok (Small and large groceries) & 14 \\
\hline Catering cégek, ételkiszállítók (Food delivery services) & 6 \\
\hline Lipóti pékség hálózata (Lipót bakery’s shops) & 6 \\
\hline Vendéglátóhelyek (Restaurants, snack bars) & 4 \\
\hline
\end{tabular}

Forrás (Source): Vállalati adatok (Data from company)

A vásárlókról, a végső fogyasztókról érdemi információkkal nem rendelkeznek, nem is gyüjtöttek. Visszacsatolásokat a nagyobb beszerzőktől, közüzemi vállalkozásoktól kapnak alkalmanként, illetve a közbeszerzési eljárások keretében elért eredményeik is egyfajta visszacsatolást jelentettek. Ilyen értékesítést folytatnak pl. a kórházak, a közétkeztetést biztosító vállalkozások, üzemi konyhák felé. (Itt kell megjegyezni, hogy az árbevétel 35\%-a tőkehúsból és $65 \%$-a húskészítményekből származik. A különböző vevők eltérő arányban vásárolnak a két termékkategóriából). Az biztosra vehető, hogy a fent nevezett szegmensek eladási kínálatában nem különül el markánsan a hagyományos és a funkcionális élelmiszer, és nem különböztetik meg ők sem a hagyományos táplálkozású és az egészségtudatos fogyasztókat.
A menedzsment fontosnak tartja, hogy azon vásárlói, akik hosszú évekkel ezelőtt bizalmat szavaztak a cégnek, ne csalódjanak bennük. Csak olyan minőségű termék hagyhatja el az üzem területét - mondja az ügyvezető „amelyet gyermekeiknek és legkedvesebb barátaiknak is jó szívvel ajánlanánk, és saját családunk asztalán is szívesen látunk", s ezzel idézi is a cég honlapján olvasható cégfilozófia egyik mondatát.

Határozottan megállapíthatjuk, hogy ilyen szerény vevőinformációk alapján nem lehet célcsoport orientált marketingstratégiáról beszélni. Hangoztatják ugyan, hogy nem a tömegtermelőkkel akarnak versenyezni. Azonban ebben a vevőcsoportosításban kétséges, hogy milyen módon különítik el a számukra fontos prémium szegmenseket, illetve hogyan ismer- 
hetik meg a szegmens tagjainak igényeit, elvárásait, szokásait, valamint értékrendjét. Érthető persze, hogy a kisvállalat teljes vevőköre sem lehet túl nagy. Ám ezek eléréséhez meg kellene találni az információs és értékesítési csatornákat is. E vevók megtalálásához kiinduló alap lehet a földrajzi elhatárolás vagy az értékesítési csatornákon keresztül való kapcsolat. Valamilyen információs kapcsolatra feltétlenül szükség van ahhoz, hogy az ismeretek begyüjthetők legyenek a piaci rést meghatározó és a rájuk irányuló döntésekhez.

\subsection{Marketing-mix - Marketing-mix}

A vállalkozás piaci eredményeit meghatározó piaci aktivitás a vezetés marketingdöntéseiben, a cég által alkalmazott marketingmixben jelenik meg. Elemzésünket a marketingmix klaszszikus 4P modellje mentén bontjuk ki.

\subsubsection{Termékek - Products}

Nem véletlen, hogy a marketingmix első és legfontosabb eleméről már sok információ hangzott el. Ez egyértelmű megnyilvánulása a vállalatvezetés termékközpontú beállítottságának, hiszen a cégalapítás körülményei és a vezetők felkészültsége is ezt alapozza meg. A piaci jelenlét - a sikerek és a felismerés - ugyan folyamatosan előtérbe hozza a vevőorientáció fontosságát is, de az STP tervezési logika, a megfelelő méretű és elérhető célcsoport kiválasztását és elvárásainak megismerését követő termékfejlesztés még nem érhető tetten a cégirányításban.

Az üzletpolitika meghatározója, hogy a termékeik hagyományos ízeikkel és a jelenkori egészségtudatos trendeknek való megfeleléssel is közel álljanak vásárlóik igényeihez. Ragaszkodnak a legjobb minőségű alapanyagokhoz, és ezek termékké formálódásának minden lépését felkészült hentesmesterek felügyelik. A termékek ízét a receptúra határozza meg, és ebben a helyi ízek, a sótartalom csökkentése, az allergén kiegészítők kerülése a lényeg, amit a keverőmester gondossága biztosít.

„Az első időkben a környékbeli öreg böllérektől tanultunk, természetesen a receptúrák azóta a kor igényeinek megfelelően fejlődtek, de az üzemben készülő termékek ízvilágát az- óta is a hagyományos szigetközi receptek határozzák meg." -vallja a vállalatvezetés.

Viszonylagos rendszerességgel tartanak házon belüli kóstolókat, un. vak íz-teszteket, amikor versenytermékekkel hasonlítják öszsze saját termékeiket. Például a próbagyártást követő érzékszervi bírálatok során a lenolajat tartalmazó termékeik több esetben kedvezőbb értékelést kaptak, mint a kontroll termékek.

A termék különleges jellegét, átlagtól magasabb minőségét érzékeltetik a csomagolással is. A kommersz áruikat gyöngyház színú csomagolásba burkolják, a prémium termékek arany és fekete színű csomagolást kapnak.

A termékfejlesztésben és a választékalakításban erőteljes rugalmasság érvényesül, ami a vállalkozás kis méretének és a technológia nem túlzott gépesítettségének köszönhető. İgy tudják megoldani, hogy ha egy partner előáll valamilyen különleges kéréssel, azt kikísérletezik és létrehozzák a kívánt új, esetleg csak annak az egy partnernek szállított terméket, akár kis tételben is. A rugalmasságuk révén egyedi megrendeléseket is teljesítenek: különleges tömegü virsli a kórházaknak, vagy specifikus méretúek egyes vendéglátóhelyeknek, máskor díszcsomagolás összeállítása stb. Az egyedi kiszállítások jelentőségét jól mutatja az is, hogy az árbevétel 11\%-a ebből a szegmensból származik, amiről több partneri levél is tanúskodik.

A termék és termelési információk alaposak, sokrétűek, de látszólag fel sem merül e kérdés kapcsán a vevő, a vevő megismerhetô igénypreferenciája, a vevőkör megbecsülhető mérete és keresletének prognosztizálható nagysága: minek is, hisz jönnek a megrendelések, viszik a terméket.

\subsection{2. Árak-Prices}

A cég vezetése tudja, hogy komoly árversenyben kell helytállnia. Árképzésüknek két pillére van: az árkalkuláció és a versenyárak megfigyelése (időnként partnereiktől kapnak információkat azok beszerzési árairól). Stratégiai megfontolásnak talán az értelmezhető, hogy a magas minőségre pozícionálnak. Minőség-érték tesztek vásárlói körben való lebonyolításának gondolata még nem merült fel, pedig tudható, hogy a hagyományos magyar élelmiszerekért a megkérdezett vásárlók több mint 
fele hajlandó lenne ár-prémiumot fizetni, és a felár a fogyasztók többsége szerint akár 10\% is lehet. A húskészítmények esetében ez a felár akár a duplája is lehet. Meg kell jegyezni azonban, hogy a válaszadók több mint 40\%-a eleve elutasítja az ilyen árdifferenciálást (SZAKÁLY et al., 2009).

Az árréssel való elégedetlenség erős a vezetésben, de egy formális lefölözéses árstratégia, mint vezetői útmutatás nem került megfogalmazásra. Ez inkább csak elképzeléseikben, vágyaikban szerepel, mert azt tudják, hogy már csak méreteik miatt sem képesek versenyezni az alacsony árfekvésű tömegtermékekkel. Az árlefölözés érvényre juttatásához, elfogadtatásához a csomagolás minőségkategóriákat megkülönböztető jellegén és a származási helyre utaló elnevezésen kívül nem használnak egyéb szükséges marketingelemeket (pl. egyedi értékesítési csatorna, erős kommunikáció).

\subsection{3. Értékesítési csatornák - Distribution Channels}

Az értékesítési rendszer fejlődése követte a termelés bővülését. Kezdetben a saját (JÓ-KER Hús kft-jük által üzemeltetett) boltjaikban került piacra a termék, és eleinte e boltok számát növelték. 2012-ben a közeli Lipóti Pékséggel - a régi személyes kapcsolatokra építve és közös értékeket vallva - jött létre egy eladási együttmúködés. A Darnó-Hús számára a Lipóti Pékségekben való megjelenés a márkaépítés szempontjából volt fontos, hiszen a Lipóti kenyér hírneve és imázsa a magas értékü, házi jellegü ízek üzenet erősítését jelentette az ott forgalmazott húskészítmények esetében is. Tudták persze, hogy ott nem sokat adnak el a termékeikből. Egy ideig a Cserpes tejtermékek is megtalálhatók voltak ezekben a boltokban, de miután a Lipóti Pékség 2016-ban létrehozta a saját Lipóti tejkészítményeket, a Cserpes visszavonult. Ezzel egyidejúleg a Darnó-Hús is eltűnőben van ebből az üzlethálózatból.

A magas minőségű, hagyományos receptúrájú termékek értékesítésére jó ötlet volt a Lipóti Pékség, amely egyértelmú imázs-transzfert jelentett, jelenthetett volna. A pékárúk és a friss tej és tejtermék megszokott termékkapcsolat a kereskedelemben, de a húskészítmények nem illettek ebbe a körbe. Nyilván ez is hozzájárult a sikeresnek indult kísérlet három év alatti visszaszorulásához.

A szállítást eleinte csak saját szállító eszközökkel bonyolították, de ahogy a Lipóti Pékség révén tágult a bolthálózat (már nem csak a Győr-Sopron, Vas és Komárom-Esztergom megye, valamint Budapest volt a szállítási célterület) egy szállítmányozó cég bevonására is szükségük volt. E szállítmányozó cég a Nutrifer Kft., amellyel az együttmúködés jónak tekinthető. Minthogy az áruterítést a szállítmányozó céggel országos szintüre bővítették, új partnereik köre is bővült, legutóbb például egy nyírségi húsnagykereskedő céggel. Mindazonáltal tudják, hogy a mennyiségeik miatt, és a kapacitásaik okán is csak kisméretű szereplők a magyar hús- és húskészítmény piacon.

$\mathrm{Az}$ 1. kép a cég honlapján felsorolt „ízlelő-helyeket” mutatja, amelyek általában kisboltok, és közöttük szép számmal szerepelnek a Lipóti Pékség boltjai (miközben a Darnó termékek egyre több helyról eltüntek).

Jelenleg kb. 250 értékesítési pontjuk van az országban, és ebben már több Tesco Áruház is megtalálható. 2010 júniusában a Tesco Sopronban szervezett egy regionális Beszállítói Fórumot, ahol a nagyvállalat képviselői négy megye, Győr-Moson-Sopron, Zala, Vas és Veszprém megye kis- és középvállalkozóival találkoztak. A Darnó-Hús azóta partnere a Tesconak, ami a márka penetrációjában érdemi bővülést hozott.

A Tesco árutömege és imázsa viszont semmiképp nem erősíti a magas minőség imázs megtapadását a vásárló emlékezetében (ami a pozicionálás lényege lenne). Ráadásul ez pont az a piaci tér, ahol a cégvezetés által nem kívánt nagytömegü, alacsony árfekvésü termékekkel kerül közvetlenül összehasonlításra a Darnó-Hús. Még akkor is, ha kiemelten a márkás termékek körében kerül kihelyezésre, de itt is elnyomják az erősebb márkák: a Pick, a Herz, a Gyulai, a Wiesbauer, stb.

Meg kell jegyezni, hogy 2016 nyarán az „ízlelőhelyek" közül számos címen nem volt megtalálható a Darnó-Hús, és az említett régiók Tesco áruházaiban is sokszor hiába kereste a vásárló ezeket termékeket. Ezek az áruhiányok kimondottan gyengítik a márkahüséget, mert a vásárló számára fontos elvárás, hogy a keresett márkát a megszokott helyen megtalálja. 
1. KÉP

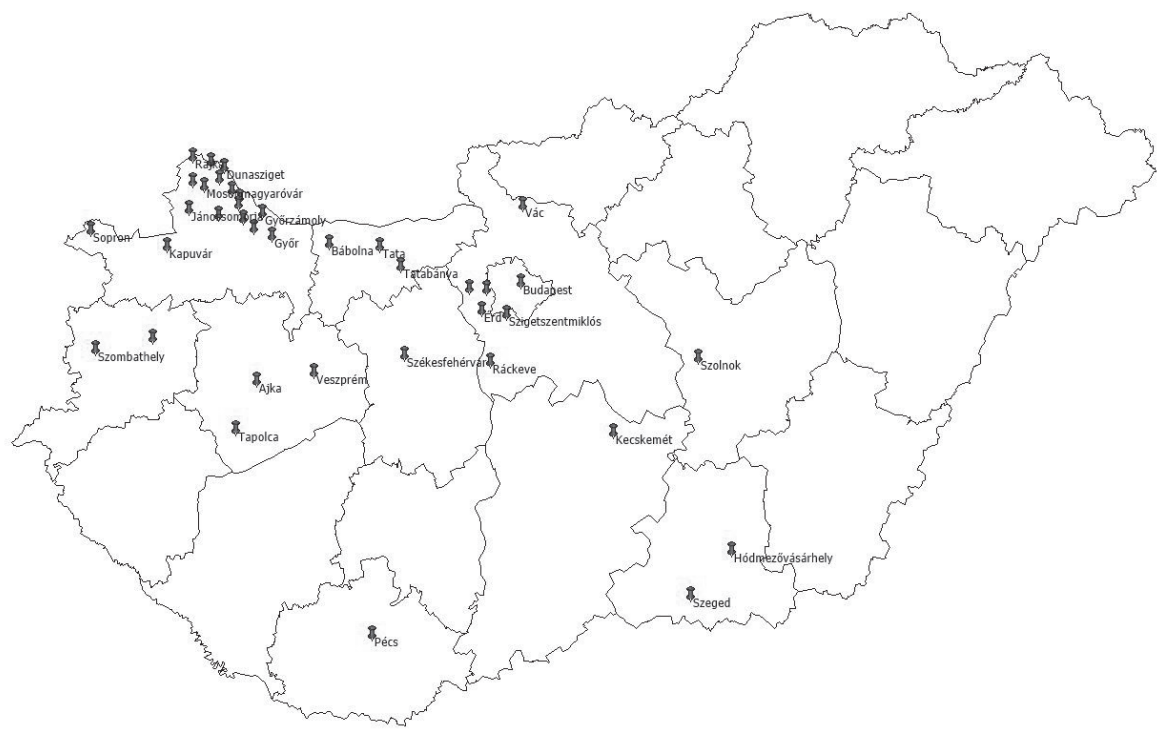

PIC. 1

Darnó-Hús ízlelö-helyek az országban

(Gustatory Places of the Darnó-Hús in the Country)

Forrás (Source): DARNÓ-HÚS (2016)

\subsubsection{Kommunikáció, márkaépítés - \\ Communication, Branding}

Hogy mennyire családi vállalkozásról van szó, azt a legjobban az igazolja, hogy a Darnó-Hús első logójának eredeti példánya (2. kép) - a tulajdonos édesanyjának sajátkezű hímzése - a vezetői iroda falán látható.

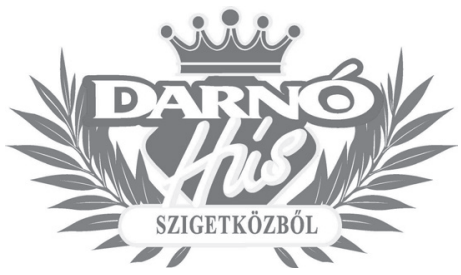

PIC. 2

2. KÉP

A Darnó-Hús első emblémája, régi céglogó (The First Logo of the Darnó-Hús) Forrás (Source): DARNÓ-HÚS (2016)

A 15 éves logót 2010/2011 fordulóján cserélték le egy új, visszafogottabb grafikára (3. kép), amelyen a nemzeti színü szalag markánsabb megjelenítése tudatos döntés volt, hiszen már a régi, a mama által gyönggyel kihím- zett logón is megtalálhatók a magyar trikolór színei. Ezzel is hangsúlyozni akarják a termék hazai, magyar jellegét.

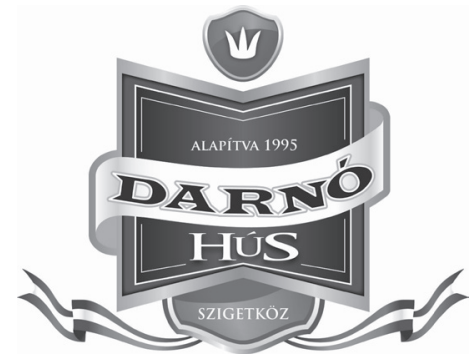

3. KÉP

$$
\text { A Darnó-Hús új céglogó }
$$

PIC. 3

(The New Logo of the Darnó-Hús)

Forrás (Source): DARNÓ-HÚS (2016)

Az új logó természetesen a termékcsomagolások meghatározó jelölése.

Más tudatos, előretervezett stratégiát követő marketingkommunikációs megjelenésról nem igen lehet számot adni: „Termékeink hirdetésére nem fektettünk hangsúlyt, de arra mindig törekedtünk, hogy tisztességgel kiszolgáljuk partnereinket, ne okozzunk csalódást 
sem a termékeink, sem pedig a kiszolgálás minőségét illetően.” - magyarázta az ügyvezető.

Tömegkommunikációs reklámokat nem alkalmaznak, ami érthető, hiszen azok költsége és terítése messze meghaladja a vállalkozás gazdasági és piaci lehetőségeit. Nagy hangsúlyt helyeznek azonban a magasra pozícionált termék-imázs kialakítására. Ezért indultak már többször is a Magyar Termék Nagydíj megmérettetésen, amelynek keretében alapos termékvizsgálatokon esnek át a nevezett termékek. Gyakran vesznek részt hazai és külföldi kiállításokon, rendezvényeken fóleg a területi kereskedelemi kamara szervezésében, ahol alkalmanként találnak is egy-egy külföldi megrendelőt. Ezek többsége - még ha kis tétellel is - visszatérő kivitelt jelent a számukra.

Több helyi és környékbeli rendezvény támogatói között is ott találjuk a márkanevet, ezekről rövid tudósítások és fotók is megjelennek a vállalat honlapján. Így jutottak el tudományos tanácskozásokra, városi rendezvényekre, bornapokra. Az ilyen kóstolók, bemutatkozások rendszerint új partnereket is hoznak, akár nagy, de többnyire csak eseti jellegü megrendeléseket.

Tisztában vannak azzal is, hogy az allergénmentesség marketing lehetőségeit még nem használták ki, a termékcsomagolásaikon ez nincs rajta, és ezen is változtatni is akarnak.

A honlapot és a Facebook megjelenésüket most korszerüsítik, átalakítják, frissítik és interaktívvá teszik.

A cég nem foglalkoztat fó állású marketingest vagy reklámost, a vezetők döntenek a szükséges piaci lépésekről, illetve megkeresésékre való reagálásról.

A reklám, a szélesebb körü marketingkommunikáció hiánya jól érzékelhető a vezetőség számára, hiszen a márka ismertsége a vásárlói kör bővülésében, az eladás növekedésében és a bolti termékkihelyezés jó pozícióinak megszerzésében is már érzékelhető akadályt jelent. A tömeges méretben alkalmazható kommunikáció formáját - figyelembe véve anyagi és a szállítási korlátjaikat - még nem találták meg.

\subsection{SWOT-elemzés - SWOT-analysis}

A korábban bemutatott módon a SWOT-elemzés elkészítésére összegyưltt vezetői fókuszcsoport interjú felvezetésként egy egyoldalas skálakérdőívet töltöttek ki a résztvevők a Darnó-Húsra jellemző tulajdonságokról. Ennek összegzése látható a 2. táblázatban.

A menedzsment tehát erősen (bár nem elsöprő erővel) vallja, hogy a cég odafigyel a vásárlói igényekre, és ezt a vásárlók méltányolják is, hiszen a vevők elégedettségét érzékelik a cég vezetői. Jó értéket kapott az egészséges élelmiszerként való minősítés is. Láthatóan elégedetlenek azzal, hogy a vevők nem adják meg a magas minőségért a megérdemelt árat. Ebben a kérdéskörben a termékek egyedisége kapta a leggyengébb minősítést, ami azt vélelmezi, hogy a vezetők szerint saját termékeik belesimulnak a tömegkínálatba, pedig az ez ellen való pozícionálás a tulajdonos egyik fó célja.

A SWOT-elemzés feltárási folyamatában az egyes elemekre vonatkozó gondolatok, ötletek, észrevételek összegyưjtése a nominális csoport módszer (NCM) segítségével történt. A témagyüjtést olyan nyitott kérdések segítették, amelyek a SWOT egyes elemeinek szubjektív megközelítését is megkönnyítették. A SWOT egyes elemeire vonatkozóan a jelenlévő 9 fó (és az előzetesen megküldött írott anyag) összesen 83 tényezőt jelölt meg. Ezek közül 27 a vállalat erősségeinek valamilyen megnyilvánulása volt, 25 a gyengeségeket írta körül. 15 tényező boncolgatta a külső lehetőségeket, esélyeket, és 16 szólt a veszélyekről, fenyegetettségekről.

A számos tényezőből való egyéni kiválasztás, majd a páros összehasonlításon alapuló ugyancsak egyéni pontozás eredményként a csoport által a SWOT legfontosabb meghatározóinak tartott tényezóket a 3. táblázat mutatja be. 


\section{A Darnó-Hús fő jellemzői \\ (Main Features of the Darnó-Hús)}

\begin{tabular}{lc}
\hline \multicolumn{1}{c}{$\begin{array}{c}\text { Véleménye szerint mennyire jellemzó a Darnó-Húsra... } \\
\text { (How Does it Fit to the Darnó-Hús ...) }\end{array}$} & $\begin{array}{c}\text { Értékelési átlagpont } \\
\text { (Evaluation Score) }\end{array}$ \\
\hline $\begin{array}{l}\text { a vásárlók igényeinek figyelembevétele } \\
\text { (... respecting the customer needs) }\end{array}$ & 80,5 \\
\hline $\begin{array}{l}\text { az, hogy helyi terméknek tekintik } \\
\text { (... is considered as a local product) }\end{array}$ & 78,6 \\
\hline $\begin{array}{l}\text { a vásárlók elégedettsége } \\
\text { (... customer satisfaction) }\end{array}$ & 78,5 \\
\hline $\begin{array}{l}\text { az, hogy megfelel az egészséges élelmiszer követelményeinek } \\
\text { (... it meets the requirements of healthy food) }\end{array}$ & 75,5 \\
\hline $\begin{array}{l}\text { az, hogy megadják érte a magasabb árat } \\
\text { (... acceptance of the higher price) }\end{array}$ & 71,5 \\
\hline $\begin{array}{l}\text { a termékek egyedisége } \\
\text { (... the customisation of the products) }\end{array}$ & 66,9 \\
\hline
\end{tabular}

Forrás (Source): Saját szerkesztés (Own construction)

Megjegyzés (Notes): Az értékelésnél 100= teljesen, tökéletesen (The interpretation of $100=$ completely, perfectly)

\section{A SWOT-elemzés részletei \\ (Details of the SWOT-analysis)}

\begin{tabular}{|c|c|c|c|}
\hline $\begin{array}{c}\text { Erôsségek } \\
\text { (Strengths) }\end{array}$ & $\begin{array}{l}\text { Gyengeségek } \\
\text { (Weaknesses) }\end{array}$ & $\begin{array}{c}\text { Lehetôségek } \\
\text { (Opportunities) }\end{array}$ & $\begin{array}{l}\text { Veszélyek } \\
\text { (Threats) }\end{array}$ \\
\hline $\begin{array}{l}\text { Kiváló minőségű } \\
\text { termékek (High- } \\
\text { quality products) }\end{array}$ & Márkaépítés (Branding) & $\begin{array}{l}\text { Igény a minőségi } \\
\text { termékekre (Need for } \\
\text { high- quality products) }\end{array}$ & $\begin{array}{l}\text { Olcsó tömeggyártás } \\
\text { jelenléte (Presence of } \\
\text { the low price } \\
\text { production) }\end{array}$ \\
\hline $\begin{array}{l}\text { Kiváló szakmai háttér } \\
\text { (Excellent professional } \\
\text { background) }\end{array}$ & $\begin{array}{l}\text { Marketingstratégia } \\
\text { (Marketing strategy) }\end{array}$ & $\begin{array}{l}\text { Házias ízek iránti kereslet } \\
\text { bővülése (Increasing } \\
\text { demand for domestic } \\
\text { tastes) }\end{array}$ & $\begin{array}{l}\text { Sok versenytárs, } \\
\text { versenytermék (Many } \\
\text { competitor producers } \\
\text { and products) }\end{array}$ \\
\hline $\begin{array}{l}\text { Jó tulajdonosi } \\
\text { hozzáállás (Good } \\
\text { attitude of ownership) }\end{array}$ & $\begin{array}{l}\text { Csomagolás } \\
\text { (Packaging) }\end{array}$ & $\begin{array}{l}\text { Fogyasztói tudatosság } \\
\text { erősödése (Increase of the } \\
\text { costumer consciousness) }\end{array}$ & $\begin{array}{l}\text { Árverseny (Price } \\
\text { competition) }\end{array}$ \\
\hline $\begin{array}{l}\text { Megbízhatóság } \\
\text { (Reliability) }\end{array}$ & $\begin{array}{l}\text { Alacsony árrés (Low } \\
\text { spread) }\end{array}$ & $\begin{array}{l}\text { Egészségtudatosság } \\
\text { fokozódása (Health- } \\
\text { consciousness) }\end{array}$ & $\begin{array}{l}\text { Munkaeróhiány } \\
\text { (Labour shortage) }\end{array}$ \\
\hline \multirow[t]{3}{*}{$\begin{array}{l}\text { Nyitottság az } \\
\text { innovációra (Open for } \\
\text { innovation) }\end{array}$} & $\begin{array}{l}\text { Munkaerő minősége } \\
\text { (Quality of the labour } \\
\text { force) }\end{array}$ & $\begin{array}{l}\text { A világháló lehetőségei } \\
\text { (Internet) }\end{array}$ & $\begin{array}{l}\text { Alapanyagárak emelke- } \\
\text { dése (Increasing prices } \\
\text { of stuff) }\end{array}$ \\
\hline & $\begin{array}{l}\text { Költséghatékonyság } \\
\text { (Cost-effectivity) }\end{array}$ & $\begin{array}{l}\text { Exportpiaci lehetőségek } \\
\text { (Export markets) }\end{array}$ & $\begin{array}{l}\text { Fogyasztói konzervati- } \\
\text { vizmus (Conservative } \\
\text { costumer attitude) }\end{array}$ \\
\hline & & $\begin{array}{l}\text { Kihasználható pályázati } \\
\text { lehetőségek (Feasible } \\
\text { tenders) }\end{array}$ & $\begin{array}{l}\text { Globalizáció, multi } \\
\text { kereskedők erősödése } \\
\text { (Globalisation, strong } \\
\text { multinational) }\end{array}$ \\
\hline
\end{tabular}

Forrás (Source): Saját szerkesztés (Own construction)

Megjegyzés (Notes): Az értékelésnél 100= teljesen, tökéletesen (The interpretation of $100=$ completely, perfectly) 
Az egyes tömörnek tűnő kifejezések mögötti tartalmat a résztvevők kifejtették, megvitatták, így az értékeléskor mindenki ugyanazt az értelmezést használta. Láthatóan számos gondolat merült fel, és ezek tömörítése után is több irányú stratégiai lehetőség bontakozott ki. A fő stratégiai irány kiválasztása céljából minden résztvevő állást foglalt, hogy az erősségek és gyengeségek közül melyiket tartja meghatározóbbnak, illetve a külső környezet oldaláról a lehetőségeket vagy a veszélyeket tartja-e dominánsabbnak. A kilenc vezető választása a $3 \times 3$-as SWOT mátrixban a 4. táblázatban látható stratégiai irányokat jelölte ki.

A cégmenedzsment jellemzően (1 kivétellel) a vállalkozás erősségeit jelentősebbnek tartja, mint a bármennyire is meglévő és ismert gyengeségeket. Véleményük szerint ezeket a cég fel tudja számolni. Abban azonban erősen megoszlanak a vélemények, hogy a külső környezetben a lehetőségekre vagy a veszélyekre kell-e jobban odafigyelni. Ebből következik, hogy a vezetésben a támadó és a védekező stratégia közötti választás vitáját még le kell folytatni, és a pontosabb piaci információk, valamint az erőforrások ismeretében kell dönteni a következő évek stratégiájáról.

Arra az anomáliára azért érdemes felhívni a figyelmet, hogy amíg a tulajdonos a márkaépítést az egyik legfontosabb piaci feladatnak látja anélkül, hogy a marketingaktivitásra különösebb figyelmet fordítana, a vezetői közösség a márkaépítést a legnagyobb gyengeségnek tartja, talán éppen a marketingstratégia hiányosságai miatt.

Stratégiai lehetôségek a 3 x 3-as SWOT mátrix alapján (Strategic Options by the $3 x_{3}$ SWOT Matrix)

\begin{tabular}{|c|c|c|c|}
\hline \multirow{2}{*}{\multicolumn{2}{|c|}{ 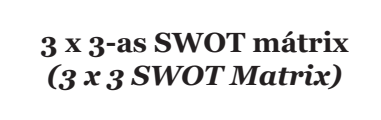 }} & \multicolumn{2}{|c|}{ Külső környezet (External Environment) } \\
\hline & & \multirow{2}{*}{$\begin{array}{l}\text { Lehetőségek } \\
\text { (Opportunities) } \\
\text { Támadó stratégia: } 4 \text { szavazat } \\
\text { (Offensive strategy } 4 \text { choices) }\end{array}$} & \multirow{2}{*}{$\begin{array}{l}\text { Veszélyek } \\
\text { (Threats) } \\
\begin{array}{l}\text { Védekező stratégia: } 4 \text { szavazat } \\
\text { (Defensive strategy } 4 \text { choices) }\end{array} \\
\end{array}$} \\
\hline $\begin{array}{l}\text { Belső } \\
\text { llapotok }\end{array}$ & $\begin{array}{l}\text { Erôsségek } \\
\text { (Strengths) }\end{array}$ & & \\
\hline $\begin{array}{l}\text { (Internal } \\
\text { States) }\end{array}$ & $\begin{array}{l}\text { Gyengeségek } \\
\text { (Weaknesses) }\end{array}$ & $\begin{array}{l}\text { Feljavító stratégia: } 1 \text { szavazat } \\
\text { (Upgrading strategy } 1 \text { choice) }\end{array}$ & $\begin{array}{l}\text { Átpozícionáló stratégia: o szavazat } \\
\text { (Repositioning strategy no choice) }\end{array}$ \\
\hline
\end{tabular}

\section{KÖVETKEZTETÉSEK ÉS}

\section{JAVASLATOK - CONCLUSIONS AND} SUGGESTIONS

Az interjúk, a strukturált és a kötetlen beszélgetések nyomán kialakult kép sok információt tartalmaz a jó eredményeket hozó, ám ha úgy tetszik ösztönös marketingdöntésekről. A szakmai körökben elfogadott tudatos marketingstratégiai szemlélet és gyakorlat - akár annak a kisvállalati adaptációja - nem igen fedezhető fel. Az esettanulmány általános következtetései tehát megegyeznek a korábbi KKV kutatások fóbb megállapításaival: a marketingtevékenységre nem fordítanak nagy figyelmet, elért piaci sikereik az ösztönös felismeréseknek és a gyors reakcióknak, valamint néhány egyedi ötletnek, elgondolásnak köszönhetők. Erőforrás korlátjaik - tőke, kapacitás, földrajzi hatósugár - a tömegkommunikációs csatornák alkalmazását gyakorlatilag lehetetlenné teszik, és ez tovább erősíti a beszúkülést, ami ellen pedig harcolni szeretnének. E konfliktus feloldására külső szakértő segítséget nem vesznek igénybe.

A marketingköltségek kérdése a cég vezetôivel lebonyolított interjúkon csak marginálisan került szóba. A vezetés egyelőre nem tartja szükségesnek a marketingmódszerek szisztematikus alkalmazásához értő marketingszakember felvételét, hiszen piaci nehézségeik - ha egyáltalán vannak - azok inkább kapacitásproblémákra vezethetők vissza. Azt felismerték, hogy a vásárlók nagy része árérzékeny, és leginkább alacsony árakat várna el tőlük, de vevőiket nem ebben a szegmensben keresik. Véleményük szerint a kiemelkedő minőséget meg is kell fizetni. Méreteik tudatában csak kevés helyen találhatók meg a piacon, ezek a piaci 
jelenlétek azonban nem köthetők valamilyen egyedi szegmensigényhez. Exporttevékenységük pedig csak esetlegesnek mondható.

A vezetés marketingismeretei túlnyomó részt az üzletmenet során szerzett tapasztalatokból származnak, még csak az sem mondható, hogy a reklám és a marketing közé egyenlőségjelet tesznek. Sokkal fontosabbnak tartják a közvetlen vevőkapcsolatokat, és a vevőktől így megismert igények rugalmas kielégítését. Marketingszempontból hasznosnak tartják az árubemutatókat, kóstolókat, ezért akár szponzorációval is részt vesznek - fóleg a környékbeli - rendezvényeken.

A kisvállalkozás marketinglehetőségeiről tartott polemizálás nyomán a tulajdonos megfogalmazta legbensőbb vágyát: „Tudja, az a célunk, hogy a Darnóit vásárolni sikk legyen!” A kérdés most már csak az, hogy milyen stratégiát kövessen ez a gyarapodó, erősödő kisvállalkozás, hogy a tulajdonos álmai megvalósuljanak?

A kérdés távolban keresendő megválaszolásához sok mindenről árulkodik és kapaszkodót is ad - ha stratégiai tervezés-módszertani elemei nincsenek is - a cég honlapján olvasható filozófia, amely nem a „nagytételben gyártott tömegcikkekben”, nem is az „esztelen ár versenyben”, hanem a „házias íz-világban” és a „kiváló minőségű termékekben” fogalmazza meg a cég lényegét.

A vállalkozás mérete, a megismert sajátosságai és értékei alapján nyilván csak a „niche-“ (a rés-) stratégia következetes alkalmazása vezethet el a tulajdonos céljainak megvalósításához. Ennek lényegéről a szakirodalom kellő útmutatást ad, aminek lényege, hogy a résekben meghúzódó vállalat ismerje meg a megcélzott fogyasztóit és mindenki másnál jobban elégítse ki igényeiket, egyértelmüsítse termékeit mind tulajdonságaiban, mint kommunikációs mondanivalójában a piaci rések számára (TEVFIK, 2006). Csak azzal érvényesíthet megfelelő ártöbbletet a költségei fölött, ha ezeket a törekvéseket a piac értékítélete elfogadja. A piaci résekre összpontosító cég a magas árrésből, és nem a tömegpiacok nagy mennyiségű vásárlásaiból tud hasznot húzni (POLERECZKI, 2011). Az egy más kérdés, hogy az így egy csoportba sorolt fogyasztói klasztereket tovább lehet szegmentálni az egészségmagatartás, a tévhitek, a hiedelmek, az attitűdök alapján. Ennek következtében egyre több olyan kisméretú, speciális piaci csoport határozható meg, amelyekben a magas minőségű termékek jó piaci eredményeket mutathatnak fel (SZAKÁLY, 2009). Ehhez pedig akár kis méretekben is nagyon tudatosan kell meghatározni a termékspecifikumokat, kommunikációs üzeneteket és csatornákat, valamint az eladási helyeket, körülményeket. Nem elég a precíziós termelés, precíziós marketing is szükséges.

A Darnó-Húsnál meg vannak győződve a vezetők ezekről a képességeikről, a kérdés azonban az, hogy hogyan tudja azonosítani ezeket a fogyasztókat. Azzal is szembesülniük kell, hogy hogyan juttassák el hozzájuk a termékeiket és hogyan tájékoztassák a megcélzott vásárlóikat. Csak így tudnak majd magasabb árrést érvényesíteni. A fogyasztói igények és megfelelő termékfejlesztési irányok összehangolásához professzionális piackutatásra, jól kiválasztott értékesítési csatornákra, folyamatos vevőtájékoztatásra és visszacsatolásra is szükség van. Ez a kulcsa, hogy biztosítani tudják a magas szintű vevőelégedettséget, a visszatérő vásárlókat, a stabil piaci jelenlétet és a tartós üzleti sikert. Ezt a célt akár a támadó, akár a védekező stratégia mentén kívánják elérni, a márkaépítés erősítése szükséges, amihez a kommunikációban döntő fontosságú lesz a pozícionálás. Ebben pedig arról is dönteni kell, hogy az emocionális vagy a racionális érvelés kerül-e a középpontba, ám ehhez a házias ízek és a funkcionális élelmiszerek közötti közös nevezőt is meg kell találni. Még szerencse, hogy az innovációra való nyitottságot - a SWOT-elemzés szerint - a menedzsment a Darnó-Hús erősségei között tarja nyilván. 


\section{IRODALOMJEGYZÉK - REFERENCES}

Darnó-Hús: URL: http://www.darno-hus. hu/ (Letöltés dátuma: 2016. máj. 6.)

Karda L.: A kis- és középvállalatok stratégiai vezetése. Doktori értekezés. NyugatMagyarországi Egyetem, Sopron, 2009.

Katona F.: Kisvállalati marketingtervezés időbeliségének a vizsgálata. Vállalkozásfejlesztés a XXI. században. Óbudai Egyetem, Budapest, 2014.

Kindler J.: A csoportos döntések korszerú módszerei, különös tekintettel a Nominális Csoport Módszerére (NCM). BME munkaköri jegyzet. Budapest, 1978.

Kürthy G.: A magyarországi húsipar helyzete nemzetközi összehasonlításban. Magyar Agrárközgazdaságtudományi Egyesület III. Konferenciája, Budapesti Corvinus Egyetem, 2015. máj. 12.

Magyar Z.: Kisvállalatok stratégiai prioritásainak vizsgálata az észak-alföldi régióban. Doktori értekezés. Szent István Egyetem, Gödöllő, 2009.

Magyar Termék Nagydíj: URL: http:// www.termeknagydij.hu/ (Letöltés dátuma: 2016. ápr. 18.)

Polereczki Zs.: A tej- és húsiparban múködő kis- és közepes vállalkozások marketing tevékenységének vizsgálata Magyarországon. Doktori értekezés. Kaposvári Egyetem, 2011.

Polereczki Zs. - Szabó G.: A tej- és húsiparban múködő kis- és közepes vállalkozások marketingsajátosságainak vizsgálata Magyarországon. Verseny élesben - Nemzetközi konferencia. CD kiadvány. Nyugat Magyarországi Egyetem Mezőgazdaság- és Élelmiszertudományi Kar, Mosonmagyaróvár, 2005. máj. 5-6.
Popovics A. - Gyenge B.: A hagyományos magyar élelmiszerek fogyasztói magatartásának vizsgálata. 2016. URL: http://www.eoq.hu/debr/koz156-208.pdf (Letöltés dátuma: 2016. jún. 29.)

Rekettye G.: Kisvállalati marketing. Akadémiai Kiadó, Budapest, 2007.

Rekettye G: Marketing a magyar kisvállalatoknak. Akadémiai Kiadó, Budapest, 2012.

Szakály Z.: Egészségmagatartás és funkcionális élelmiszerek: hogyan vélekednek a hazai fogyasztók? Élelmiszer, Táplálkozás és Marketing. 2009. 6 (1-2) 9-18.

Szakály Z. - Kiss M. - Jasák H.: Funkcionális élelmiszerek, fogyasztói attitűdök és személyre szabott táplálkozás. Táplálkozásmarketing. 2014.1 (1-2) 3-17.

Szakály Z. - Szente V. - Szigeti O. Polereczki Zs.: A hagyományos magyar élelmiszerek fogyasztói megítélése, különös tekintettel a magyar szürke marha és mangalica termékekre Élelmiszervizsgálati Közlemények. 2009. 55 (1) 9-27.

Tevfik, D.: Handbook of Niche Marketing. Principles and Practice. Best Business Books. The Haworth Reference Press, New York, 2006. 